anxiety and depressive symptoms, and (4) depressed patients who stop medication complaining of side effects do not necessarily do so because these are pharmacologically induced.

We would thank the Research Committee of the Victorian Branch of the Australian College of General Practitioners for their co-operation and help. We would especially thank the individual general practitioners: Drs. D. Brodie, Blackburn South; D. Buchanan, Bulleen; T. Connors, Essendon; J. Downes, Toorak; J. Egan, Blackburn South; C. Gutch, Clifton Hill; L. Hartman, East Brunswick; D. Kaplan, Ashwood; G. Miles, Clifton Hill; M. Nissen, Windsor; K. Owen, Blackburn South; B. Phillips, Bulleen; J. Riddell, Balwyn; J. Sanders, Footscray; T. Springer, Melbourne; J. Starr, Ivanhoe; D. Stewart, Clifton Hill; H. Sutcliffe, Pascoe Vale; E. Thurin, Toorak; T. Wawryk, Pascoe Vale; R. Williams, Lower Templestowe. We also thank Miss Roslyn Sibbald for coordination of appointments between psychiatrist and patients. We are grateful to Dr. Richard Mulhearn, of Roche Products, for his help and for supplying the capsules.

\section{References}

Carroll, B. J., Mowbray, R. M., and Davies, B. (1970). Lancet, 1, 967. Davies, B. (1968). Australian and New Zealand fournal of Psychiatry, 2, 194. Fielding, J. M., Mowbray, R. M., and Davies, B. (1969). Medical fournal

of Australia, 2, 851.
Fry, J. (1961). Guy's Hospital Gazette, 75, 453.

Hamilton, M. (1960). . Fournal of Neurology, Neurosurgery and Psychiatry, 23,56 .

Hamilton, M. (1967). In Drugs and the Mind, p. 80. Dunedin, University of Otago Press.

Jones, F. L. (1967). Australian and New Zealand fournal of Sociology, 3, 93.

Jones, I. H. (1967). Medical fournal of Australia, 1, 202.

Klerman, G. L., and Cole, J. O. (1963). Pharmacological Reviews, 17, 101. Lancet, 1967, 1, 1334.

Leyburn, P. (1967). Lancet, 2, 1135.

Porter, A. M. W. (1970). British Medical fournal, 1, 773.

Rickels, K., et al.(1970). Diseases of the Nervous System, 31, 30.

Shepherd, M., Cooper, B., Brown, A. C., and Kalton, G. (1966). Psychiatric Illness in General Practice. London, Oxford University Press.

Taylor, J. A. (1953). fournal of Abnormal and Social Psychology, 48, 285.

Watts, C. A. H. (1966). Depressive Disorders in the Community. Bristol, Wright.

Zung, W. W. K. (1965). Archives of General Psychiatry, 12, 63.

\title{
Y-Fluorescence of Interphase Nuclei, Especially Circulating Lymphocytes
}

\author{
P. E. POLANI, D. E. MUTTON
}

British Medical fournal, 1971, 1, 138-142

\begin{abstract}
Summary
Application of a fluorescence technique for the detection of the human $\mathbf{Y}$ chromosome in interphase nuclei indicates that the best results may be obtained from the study of lymphocytes in blood smears. The most satisfactory Y-fluorescence is obtained with the use of buffered quinacrine mustard dihydrochloride. The method can be complemented by other standard techniques to obtain a clear idea of the sexchromosome complement of the individual. The application of this technique to clinical and chromosomal diagnosis and to the prenatal detection of the $Y$ chromosome in amniotic cells seems at least as promising as has proved the earlier identification of the Barr body.
\end{abstract}

\section{Introduction}

The observation by Caspersson et al. (1968) of a specific fluorescent banding pattern in chromosomes of Vicia and other plants following treatment with the fluorochrome quinacrine mustard has generated interest in the application of this method to man (Caspersson et al., 1970a, 1970b; George, 1970a; Pearson et al., 1970). In human male metaphases the most prominent feature is a striking distal long-arm fluorescence of the $\mathrm{Y}$ chromosome (Fig. 1), which can also be observed in interphase nuclei and meiotic cells (Barlow and Vosa, 1970; Pearson and Bobrow, 1970). Work on interphase cells is particularly relevant to nuclear sexing in a variety of clinical states, but the method has been applied qualitatively and only to cultured cells and oral smears. For the technique to be proved suitable for both exact and rou-

Guy's Hospital Medical School, London S.E.1

P. E. POLANI, M.D., F.R.C.P., Professor of Paediatric Research D. E. MUTTON, B.sc. tine applications, the best and most easily accessible tissue must be identified, checks on reliability in normal and abnormal circumstances must be made, and the variability of results from technical and other sources must be assessed and quantification achieved. The present work explores the technique in relation to some of these objectives.

\section{Techniques}

After a pilot study we concentrated on the fluorescence induced by quinacrine mustard dihydrochloride (Q.M.) but quinacrine hydrochloride (Q) was also used. All solutions were freshly made up before use, but were found to remain active for at least a month when kept at $+4^{\circ} \mathrm{C}$. Q.M. (acridine, 9-[(4-[bis(2-chloroethyl)amino]-1-methylbutyl amino]-6-chloro-2-methoxy-,dihydrochloride) (see Loveless, 1970) was made up at a concentration of $250-300 \mu \mathrm{g} / \mathrm{ml}$ in $\mathrm{Mc}$ Ilvaine's buffer at $\mathrm{pH}$ 4.0-4.5. Slides were fixed in methanol for blood smears, methylated spirit $(95 \%$ ethanol) for oral smears, and 3:1 ethanol-glacial-acetic for fibroblasts and amniotic cells, and the fixed slides were allowed to dry, washed in buffer for five minutes, stained in Q.M. solution for 15 minutes, rinsed in buffer, and mounted in buffer (George, 1970b). The coverslips were ringed with nail varnish.

$\mathrm{Q}$ (Atebrin) $0.5 \%$ was used either as aqueous solution (Q.A.) or in McIlvaine's buffer at $\mathrm{pH} 4.5$ (Q.B.). In the former case slides were washed in deionized water, stained for five minutes, washed in running tap-water for three minutes, and mounted on buffer at $\mathrm{pH} 5.5$ (Pearson et al. 1970). Conversely, Q.B. was applied for 15 minutes to slides washed in buffer at pH 4.5, which was also used to rinse and as a mountant. Preparations of cells from fresh amniotic fluid were made by spinning the fluid at 1,000 r.p.m. for five minutes, suspending the sediment in Hanks's balanced salt solution to wash, respinning as above, fixing and suspending the pelleted cells, resedimenting them, and taking them up in a small amount of fresh fixative to make air-dried preparations; direct smears from the sedimented cells, air-dried and fixed, were also satisfactory. 
TABLE 1-Y-fluorescence of Interphase Nuclei Stained with Quinacrine Mustard Hydrochloride (Q.M.) or Quinacrine Hydrochloride (Q) in Water or Buffer (rounded off percentages)

\begin{tabular}{|c|c|c|c|c|c|c|c|c|}
\hline & \multirow{2}{*}{ No. } & \multirow{2}{*}{$\begin{array}{l}\text { Fluoro- } \\
\text { chrome }\end{array}$} & \multirow{2}{*}{$\begin{array}{l}\text { Cell } \\
\text { Type }\end{array}$} & \multicolumn{4}{|c|}{ Y-Fluorescence } & \multirow{2}{*}{ Comments } \\
\hline & & & & + & \pm & - & Range & \\
\hline Males & $\begin{array}{r}35 \\
10 \\
28 \\
5 \\
4 \\
2 \\
2 \\
\end{array}$ & $\begin{array}{l}\text { Q.M. } \\
\text { " } \\
\text { " } \\
\text { " } \\
\end{array}$ & $\begin{array}{c}\mathbf{L} \\
\mathbf{P} \\
\mathbf{O} \\
\mathbf{F} \\
\mathbf{A T} \\
\mathbf{A C} \\
\mathbf{A E}\end{array}$ & \begin{tabular}{l|}
69 \\
37 \\
57 \\
78 \\
12
\end{tabular} & $\begin{array}{r}1 \\
10 \\
4 \\
15 \\
-\end{array}$ & $\begin{array}{l}30 \\
53 \\
39 \\
7 \\
88\end{array}$ & $\begin{array}{r}61-87 \\
27-60 \\
20-88 \\
61-92 \\
7-21 \\
16,32 \\
21,23\end{array}$ & $\begin{array}{l}0.6 \% \text { with } 2 \text { Y spots } \\
1.0 \% \text { with } 2 \text { Y spots }\end{array}$ \\
\hline Females & $\begin{array}{r}30 \\
19 \\
27 \\
4 \\
3 \\
1 \\
1\end{array}$ & $\begin{array}{l}\text { Q.M. } \\
\text { ", } \\
" \\
" \\
\text { ", }\end{array}$ & $\begin{array}{c}\mathbf{L} \\
\mathbf{P} \\
\mathbf{O} \\
\mathbf{F} \\
\mathbf{A T} \\
\mathrm{AC} \\
\mathbf{A E}\end{array}$ & \begin{tabular}{l|}
5 \\
7 \\
8 \\
3
\end{tabular} & $\begin{array}{r}3 \\
22 \\
3 \\
19\end{array}$ & $\begin{array}{l}92 \\
71 \\
89 \\
78\end{array}$ & $\begin{array}{r}0-13 \\
1-22 \\
0-25 \\
1-7 \\
0-1 \\
0 \\
0\end{array}$ & $1 \cdot 0^{\circ}, j$ with 2 Y spots \\
\hline Males & $\begin{array}{l}12 \\
12 \\
12 \\
12 \\
\end{array}$ & $\begin{array}{c}Q \text { water } \\
\mathbf{Q} \text { buffer } \\
\text { " }\end{array}$ & $\begin{array}{l}\mathbf{L} \\
\mathbf{P} \\
\mathbf{L} \\
\mathbf{P}\end{array}$ & $\begin{array}{l}44 \\
35 \\
58 \\
14\end{array}$ & $\begin{array}{r}8 \\
14 \\
10 \\
14 \\
\end{array}$ & $\begin{array}{l}48 \\
51 \\
32 \\
72\end{array}$ & $\begin{array}{r}0-71 \\
14-50 \\
27-89 \\
3-89\end{array}$ & $\begin{array}{l}2 \text { false negatives } \\
5 \text { false negatives }\end{array}$ \\
\hline Females & $\begin{array}{l}11 \\
11 \\
11 \\
11\end{array}$ & $\begin{array}{c}Q \text { water } \\
\mathbf{Q} \text { buffer } \\
\text { " }\end{array}$ & $\begin{array}{l}\mathbf{L} \\
\mathbf{P} \\
\mathbf{L} \\
\mathbf{P}\end{array}$ & $\begin{array}{l}2 \\
4 \\
2 \\
2\end{array}$ & $\begin{array}{l}5 \\
2 \\
3 \\
1 \\
1\end{array}$ & $\begin{array}{l}93 \\
94 \\
95 \\
97\end{array}$ & $\begin{array}{l}0-7 \\
0-10 \\
0-7 \\
0-7\end{array}$ & \\
\hline
\end{tabular}

$\mathrm{L}=$ Lymphocytes. $\mathrm{P}=$ Polymorphs. $\mathrm{O}=$ Oral mucosa cells. $\mathrm{F}=$ Fibroblasts. AT $=$ Amniotic fluid cells at term. AE = Amniotic fluid cells in early pregnancy.
$\mathbf{A C}=$ Cultured amniotic fluid cells from early pregnancy

After trying the method with cells of known sex we conducted the experiments on coded slides, several scored independently. In a few cases we successfully stained the slides with conventional methods subsequent to the use of the fluorochrome. Toluidine blue, lacto-acetic orcein, and Leishman-Giemsa were used, partly to study the ability of cells and metaphase spreads to take up stain after Q.M. and partly to correlate the $\mathbf{Y}$-fluorescence with staining or to observe the sex chromatin (Barr body). We also investigated the use of Q.M. fluorescence in slides previously stained with the above dyes and were unsuccessful except for aqueous toluidine blue (see below). The persistence of fluorescence and the possibility of restaining with Q.M. after fluorescence had faded were tested with varying success, but old unstained oral and blood smears and metaphase spreads were successfully stained with Q.M.

Observations with Zeiss (Oberkochen) fluorescence microscopes were usually made with a $\times 40$ oil-immersion apochromatic objective which allows easy and most brilliant and distinctive recognition of the specific Y-fluorescence. We used either a photomicroscope for transmitted light or a universal microscope with incident light fluorescence. The observations were made at about $400 \mathrm{~nm}$ UV (exciter filter BG12) with a barrier filter combination $53 / 44$. Photographically the vertical system of the universal microscope was preferable to the cassette camera of the Zeiss photomicroscope, and we now use this system also on the photomicroscope. The film of

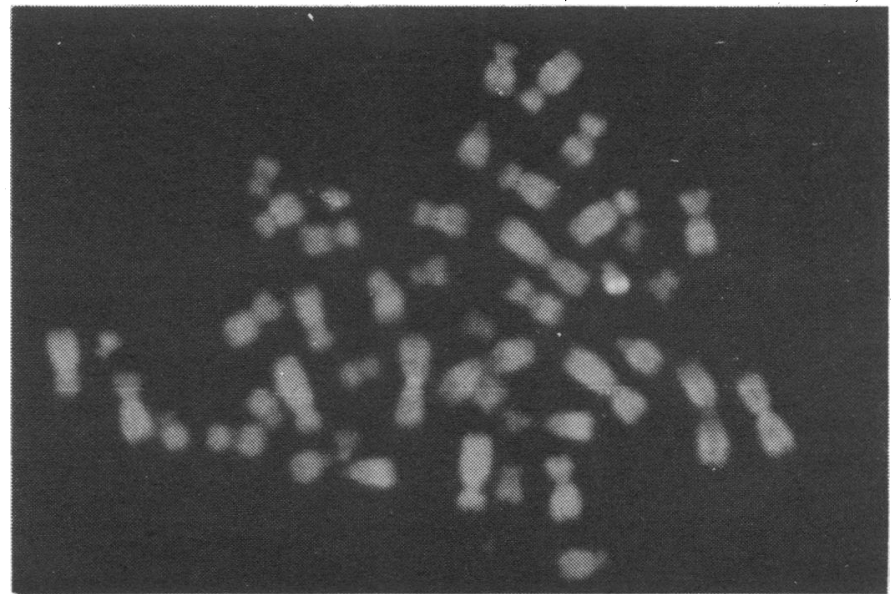

FIG. 1-Normal male metaphase chromosomes stained with quinacrine mustard (Q.M.) showing distinct fluorescence of the long arms of the $Y$ chromosome.

our choice is Gaevert Scientia 50-B-65. This relatively slow film gives very low grain level. Exposure times are about $\mathbf{4 0}$ seconds.

\section{Results}

\section{NORMAL SUBJECTS}

The technique proved simple, reliable, and generally unequivocal (Tables I and II, observers' scores pooled). Best results were obtained with Q.M. applied to well-spread blood smears for a study of the circulating lymphocytes, but good results were obtained in other tissues. Scoring lymphocytes with Q.A. we had two false-negative results, but Q.B.-stained and Q.M.-stained slides from these two subjects were Y-positive, as were the Q.A.-stained polymorphs. Scoring polymorphs with Q.B., we had several false negatives. In examining oral smears care has to be used to allow for the presence of bacteria, which can give confusing results.

In none of the subjects whose interphase nuclei were studied with Q.M. was a wrong diagnosis made concerning the presence or absence of the $Y$ chromosome, as compared with phenotype, and at times chromosome analysis, metaphase spreads treated with Q.M., and Barr-body findings (Tables I and II). Equally, a comparison between different tissues of the same subject gave univocal results.

An average of $69 \%$ of the lymphocytes from males showed Y-fluorescence with Q.M. as compared with only $5 \%$ among the females. In general, a blood smear could be classified as Y-positive practically at first glance; the doubtfully positive

\begin{tabular}{|c|c|c|c|c|c|c|c|c|}
\hline \multirow{3}{*}{$\begin{array}{l}\text { Pheno- } \\
\text { type }\end{array}$} & \multirow{3}{*}{ Karyotype } & \multirow{3}{*}{$\begin{array}{c}\text { Barr Body } \\
\text { (Sex Chromatin) }\end{array}$} & \multirow{3}{*}{ Clinical Diagnosis } & \multicolumn{3}{|c|}{ Y-Fluorescence \% } & \multirow{3}{*}{ Metaphases } & \multirow{3}{*}{ Comments and Conclusions } \\
\hline & & & & \multicolumn{2}{|c|}{ Lymphocytes } & Oral Cells & & \\
\hline & & & & +++ & $\pm \quad-$ & ++ \pm \pm- & & \\
\hline Female & $\begin{array}{l}45, X \\
45, X \\
46, X ? Y \\
46, X ? Y \\
45, X / 46, X ? Y \\
45, X / 46, X ? Y\end{array}$ & $\begin{array}{l}\text { Negative } \\
\text { Negative } \\
\text { Negative } \\
\text { Negative } \\
\text { Negative } \\
\text { Negative }\end{array}$ & $\begin{array}{l}\text { Dysgenetic ovaries } \\
\text { Dysgenetic ovaries } \\
\text { Dysgenetic ovaries } \\
\text { Dysgenetic ovaries } \\
\text { Dysgenetic ovaries } \\
\text { Dysgenetic ovaries }\end{array}$ & $\begin{array}{l}=\quad 4 \\
=\quad 68 \\
=\quad 65 \\
-\quad 20 \\
-\quad 2\end{array}$ & $\begin{array}{ll}4 & 96 \\
4 & 90 \\
4 & 32 \\
2 & 78 \\
- & 98 \\
\end{array}$ & $\begin{array}{l}-\begin{array}{c}11 \\
\text { Not done }\end{array} \\
\text { Not done } \\
-\quad 76=24 \\
-\quad 45-55 \\
-\quad 21286\end{array}$ & $\begin{array}{l}\text { Y negative } \\
\text { Not done } \\
\text { Y positive } \\
\text { Y positive } \\
\left\{\begin{array}{l}2 n=46, Y \text { pos. } \\
2 n=45, Y \text { neg. }\end{array}\right. \\
Y \text { negative }\end{array}$ & $\begin{array}{l}\text { No Y. Karyotype confirmed } \\
\text { No Y. Karyotype confirmed } \\
\text { XY } \\
X Y \\
45, X / 46, X Y \\
\text { Presumptive } 45, X / 46, X X q-\end{array}$ \\
\hline \multirow{4}{*}{ Male } & $\begin{array}{l}\text { 47,XYY } \\
47, X Y Y\end{array}$ & $\begin{array}{l}\text { Negative } \\
\text { Negative }\end{array}$ & $\begin{array}{l}\text { XYY male } \\
\text { XYY male }\end{array}$ & $\begin{array}{ll}31 & 63 \\
51 & 39 \\
\end{array}$ & 二 $\quad{ }^{6}$ & 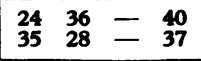 & $\begin{array}{l}\text { Not done } \\
\text { Not done }\end{array}$ & $\begin{array}{l}\mathbf{X Y Y} \\
\mathbf{X Y Y}\end{array}$ \\
\hline & $\begin{array}{l}\text { 47,XXY } \\
47, \mathbf{X X Y} \\
47, \mathbf{X X Y}\end{array}$ & $\begin{array}{l}\text { Positive } \\
\text { Positive } \\
\text { Positive }\end{array}$ & $\begin{array}{l}\text { Klinefelter's syndrome } \\
\text { Klinefelter's syndrome } \\
\text { Klinefelter's syndrome }\end{array}$ & $\begin{array}{l}=74 \\
=65 \\
-\quad 66\end{array}$ & $\begin{array}{ll}3 & 23 \\
& 35 \\
8 & 26\end{array}$ & $\begin{array}{ccc}47 & 6 & 47 \\
\text { Not done } & \\
-50 & 8 & 42\end{array}$ & $\begin{array}{l}\text { Y positive } \\
\text { Not done } \\
\text { Y positive }\end{array}$ & $\begin{array}{l}\text { Drumsticks, karyotype confirmed } \\
\text { Drumsticks, karyotype confirmed } \\
\text { Drumsticks, karyotype confirmed }\end{array}$ \\
\hline & $49, \times X X X Y$ & $\begin{array}{c}\text { Positive } \\
\text { (max. } 3 \text { masses) }\end{array}$ & XXXXY syndrome & -51 & 940 & -38656 & Not done & Drumsticks, karyotype confirmed \\
\hline & $\begin{array}{l}46, x x \\
46, x \times x \\
46, x x\end{array}$ & $\begin{array}{l}\text { Positive } \\
\text { Positive } \\
\text { Positive }\end{array}$ & $\begin{array}{l}\text { Klinefelter's syndrome } \\
\text { ?Klinefelter's syndrome } \\
\text { Klinefelter's syndrome }\end{array}$ & $\begin{array}{l}=6 \\
=\quad 2\end{array}$ & $\begin{array}{cc}9 & 85 \\
11 & 84\end{array}$ & $=\begin{array}{ccc}8 & 5 & 87 \\
& 9 & 3 \\
\text { Not done } & 88\end{array}$ & $\begin{array}{l}\text { Y negative } \\
Y \text { negative } \\
Y \text { negative }\end{array}$ & $\begin{array}{l}\text { Drumsticks, no } \mathbf{Y} \\
\text { Drumsticks, no } \mathbf{Y} \\
\text { Drumsticks, no } \mathbf{Y}\end{array}$ \\
\hline
\end{tabular}


cells in males and females never showed the sharp, often crescentic fluorescent spot that seems characteristic of the $Y$ chromosome (Fig. 2), but had duller, globular, indistinct fluorescent areas. Only one exceptional lymphocyte in a normal male seemed to have two separate fluorescent spots and very few had twin-spot or "duplex" Y-fluorescence (Fig. 3). The nuclei of the polymorpho-nuclear leucocytes of males showed Y-fluorescence, but this seems less consistent for sexing than were the lymphocytes. An attempt was made to detect drumsticks in the male and female blood smears in which the polymorphonuclear cells were scored for Y-fluorescence. In females these had about the usual frequency, while no drumsticks were seen in the white cells from normal males. The position of a few polymorphs with a typical drumstick (and little clubs) having been located in fluorescence, it was possible to confirm the presence of the characteristic cellular feature after conventional staining of the same slide and relocation of the cell (see below).

The Q.M.-treated oral smears gave Y-positive results in $57 \%$ of nuclei of males with $0.6 \%$ exhibiting two separate fluorescent spots, as in YY nuclei (see below) and about $10 \%$ with duplex Y-fluorescence (Fig. 3). Comparable results in normal female oral smears were $8 \%$ positive. A dull fluorescent spot was seen at the nuclear membrane of a proportion of cells from normal females in good preparations. By subsequent staining with orcein some of these dull fluorescent bodies could be identified as Barr bodies.

The interpretation of the Q.M. findings in fibroblasts from tissue culture obtained from subjects with normal chromosome complements was more difficult because between three and four small "fluorocentres" are seen on an average per nucleus in both males and females. However, no error of classification was made. It seemed that the Y-fluorescence was often near the nucleolus and in many fibroblasts the fluorescent spot was elongated as in lymphocytes, but in some it was present in duplex form. A control comparison with fibroblasts whose sex-chromosome complement was known was an advantage or even a necessity, though we suspect that this may not be required if the technique is constantly used.

Potentially, a study of amniotic fluid cells should be of practical and theoretical interest. Our experience is limited to 10 specimens and to Q.M., but again we made no classification errors. We scored 150 cells from each subject, and in only one of the female specimens did we find a single "Ypositive" cell. Our failure to detect a higher frequency of $\mathrm{Y}$ fluorescence in the males may be due to the fact that amniotic fluid nuclei particularly from uncultured specimens, fluoresce heavily and uniformly and are probably dead cells undergoing autolysis.

\section{ABNORMAL SEX-CHROMOSOME COMPLEMENTS}

While 45,X lymphocytes and oral mucosa nuclei (Table II) showed no Y-fluorescence and the interphase nuclei (and

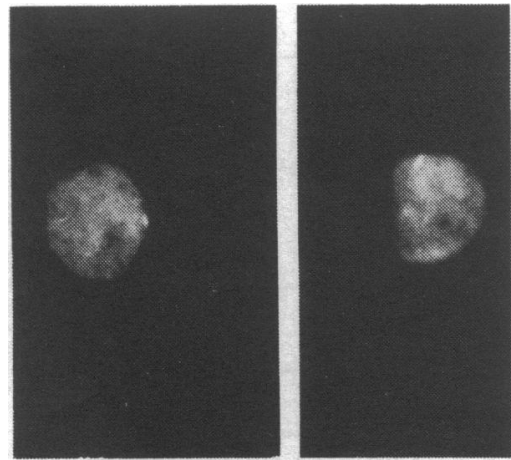

FIG. 2-Typical fluorescent spots in small lymphocytes of normal male. metaphase plates) of the $46, \mathrm{XX}$ males behaved similarly, the 47,XYY males showed an additional $Y$-fluorescent spot in about half the nuclei in which $Y$-fluorescence could be identified (Fig. 4.) The second spot could usually be clearly distinguished from the duplex $\mathbf{Y}$ found in a small proportion of oral cells and fibroblasts. We were unable to identify positively the $49, \mathrm{XXXXY}$ complement which we, however, diagnosed as a complement with at least two $X$ chromosomes (on the grounds of the presence of drumsticks in Q.M.-stained blood smears) and with one $Y$ chromosome, because of a single $Y$ spot in the lymphocytes and oral mucosa cells. The three 47,XXY males were similarly diagnosed (Fig. 5). By staining initially with $1 \%$ aqueous toluidine blue, Barr-body-positive cells could be selected for examination after Q.M. staining, it being possible to demonstrate $\mathbf{X}$ and $Y$ chromatin masses in the same cell (Fig 6).

The presence of a $\mathrm{Y}$ chromosome was confirmed in interphase nuclei (lymphocyte, oral mucosa cells) and metaphase spreads of the two non-mosaic women with dysgenetic ovaries (Table II), while the cells with 46 chromosomes of one of the two mosaic subjects, $45, X / 46, X$ ? $Y$,
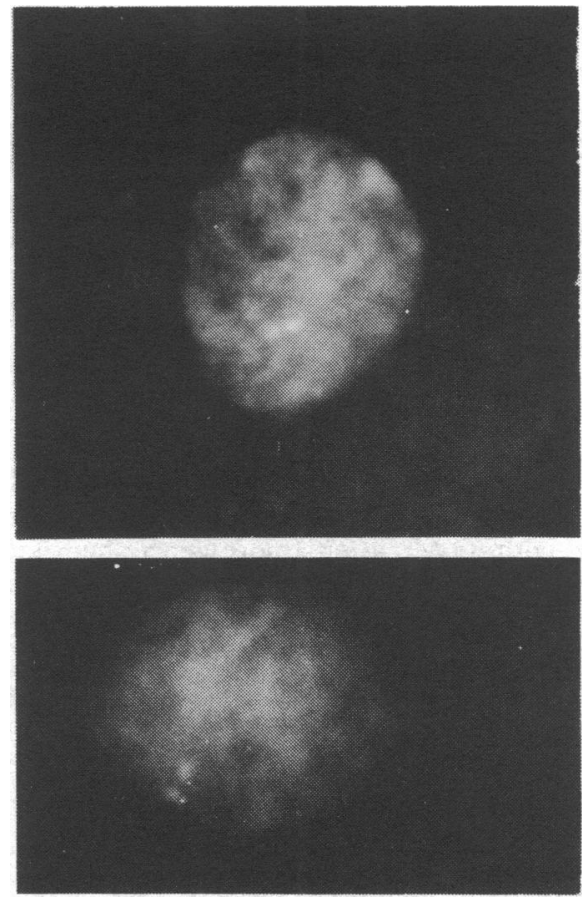

FIG. 3- "Duplex" Y-fluorescence in oral mucos cells.
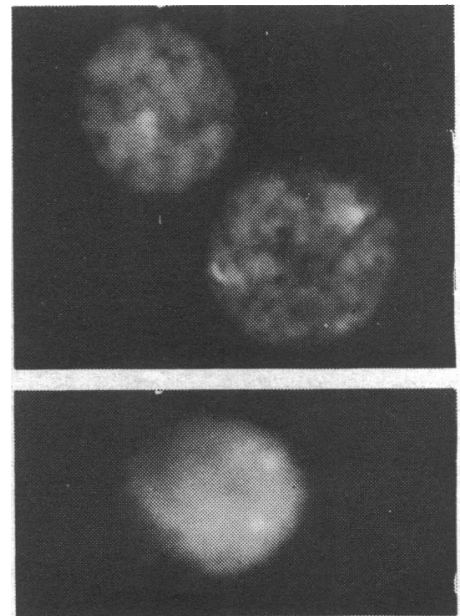

FIG. 4-Double $\mathrm{Y}$-fluorescence in mucosa cell (above) and small lymphocyte (below) of an individual with 47,XYY karyotype. 


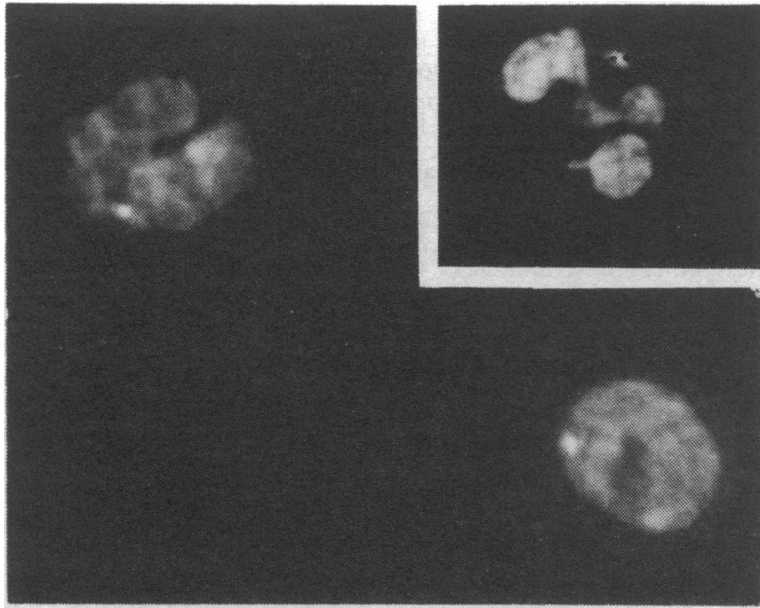

FIG. 5-Identification of Klinefelter's syndrome, 47, XXY, in blood smear by the presence of the $Y$ spot and drumstick (in inset).
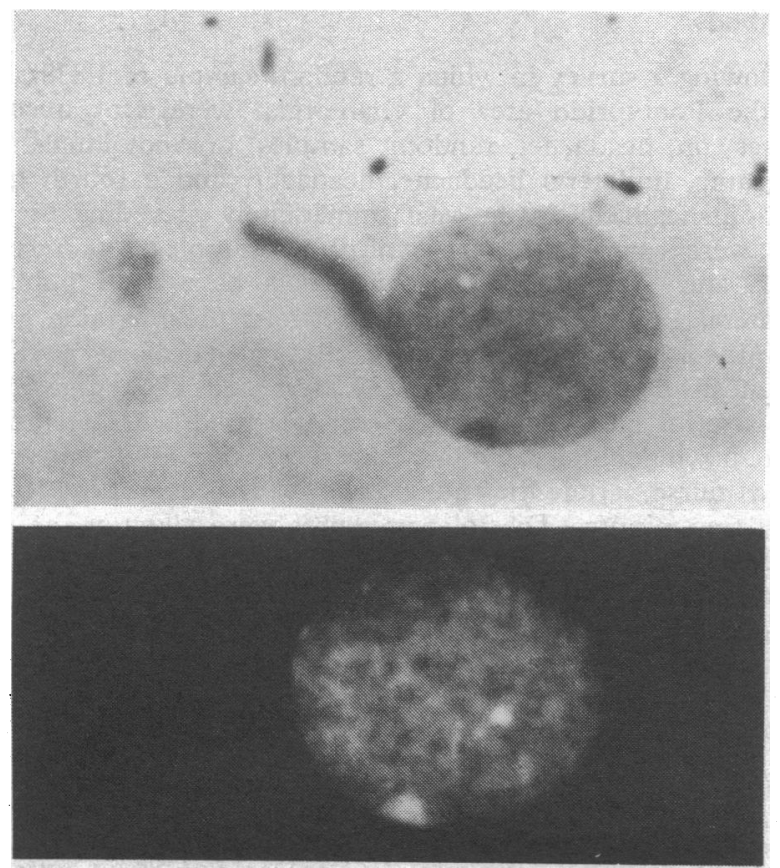

FIG. 6-Oral mucosa cell of a Klinefelter's-syndrome male, 47,XXY, stained initially with $1 \%$, toluidine blue and later with
Q.M.

gave similar results. Conversely, no specially fluorescent small acrocentric chromosome was seen in the metaphases with 46 chromosomes of the second mosaic woman; neither was there Y-fluorescence in her oral mucosa or lymphocyte nuclei, nor in the cultured fibroblasts. It was concluded that the likeliest interpretation was that the $\mathrm{Y}$-like acrocentric chromosome seen in the 46-chromosome cells of this patient was a deleted $\mathbf{X}$ chromosome (Xq-), but studies of the paternal $\mathbf{Y}$ chromosome should be done.

\section{MISCELIANEOUS FINDINGS}

Examination may be postponed for about one to two hours after preparing the slides, when Q.M.-fluorescence is stronger. Q.M.-furorescence of metaphase spreads and of oral nuclei persists and is still satisfactory for at least 24 hours. Slides originally stained with Q.M. were restained with this fluoroctrome one month later. We were unsuccessful with oral smears and fibroblasts, but in five out of seven male blood ancars, including a $47, X Y Y$ subject, a completely satis-
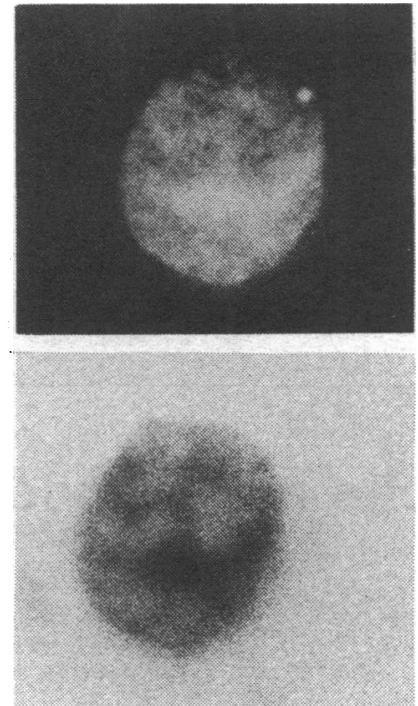

FIG. 7-Epithelioid cell derived from amniocentesis, showing fluorescent $Y$ spot and restained with toluidine blue to show small peripheral chromocentre in the same position.

factory diagnosis could be made. If we selected only those slides in which the nucleoplasm of the lymphocytes was not heavily and diffusely fluorescent, then each slide could be accurately assessed. In some cells we were able to identify a chromocentre, using aqueous toluidine blue solution, in a position corresponding to that of the Y-fluorocentre (Fig. 7).

\section{Conclusion}

When using Q.M. and blood smears a count of 30 lymphocytes should be adequate to differentiate between subjects who, in that tissue, have $Y$-containing cells and subjects whose cells have no $Y$. In the case of oral smears we think that 50 cells ought to be counted to achieve discrimination. In practice, $Y$-fluorescence, particularly in lymphocyte nuclei, is very distinctive and allows a clear-cut, first-glance recognition of $\mathbf{Y}$-positivity. The technique of $\mathrm{Y}$-fluorescence in interphase has thus complementary usefulness to nuclear sexing; unlike nuclear sexing it is directly applicable to and interpretable in metaphase spreads. The method should be particularly interesting in the study of subjects who are or may be mosaics in tissues in which cultures of representative cells may not be achieved.

The method is of interest in the study of interphase amniotic cell nuclei, but our experience is so limited that reliability of the technique should not be assumed without further extensive trials at various gestational ages, particularly in respect to uncultured cells. Our experience with fibroblasts from skin cultures is also limited, but the investigation of these cells seems promising.

Apart from accurate quantitative studies (Caspersson et al., $1970 \mathrm{~b}$ ), the fluorescence method has also usefulness in sex-chromosome identification at metaphase, particularly with respect to deletions, interchanges, or other structural anomalies of $\mathbf{X}$ and $\mathbf{Y}$ chromosomes. Clearly in these cases the most useful information will derive from combined studies of metaphase and interphase nuclei coupled with the techniques of autoradiography and sex-chromatin investigation. With respect to structural anomalies of the $Y$ chromosome, the special fluorescence behaviour of the distal part of the long arm of the $Y$ chromosome is of special interest. Though absence of this fluorescence from cells must be taken to imply that the segment that usually fluoresces is itself missing, there is the formal possibility that changes of 
the $\mathrm{Y}$ chromosome, or at least the terminal part of its long arm, might alter its reaction to specific fluorochromes.

All in all we favour the use of Q.M., which in our experience has been more consistent than Q., on peripheral blood for routine laboratory application.

Quinacrine mustard was kindly donated by the Cancer Chemotherapy National Service Center, National Institutes of Health, Bethesda, U.S.A. Mr. L. Kelberman advised on and helped with the photography. The work was supported by the Spastics Society.

\section{References}

Barlow, P., and Vosa, C. G. (1970). Nature, 226, 961.

Caspersson, T., et al. (1968). Experimental Cell Research, 49, 219.

Caspersson, T., Zech, L., and Johansson, C. (1970a). Experimental Cell Research, 60, 315.

Caspersson, T., Zech, L., Johansson, C., and Modest, E. J. (1970b). Chromosoma, 30, 215

George, K. P. (1970a). Nature, 226, 80.

George, K. P. (1970b). Stain Technology. In press.

Loveless, A. (1970). Nature, 227, 101.

Pearson, P. L., and Bobrow, M. (1970). Nature, 226, 959.

Pearson, P. L., Bobrow, M., and Vosa, C. G. (1970). Nature, 226, 78.

\title{
Headache and Blood Pressure in the Community
}

\author{
W. E. WATERS
}

British Medical fournal, 1971, 1, 142-143

\section{Summary}

Following a survey of headaches, in which questionnaires were sent to a random sample of the general population, groups of individuals with headache, unilateral headache, or migraine, and a fourth group who had not had a headache in the previous year were examined. Measurements of arterial blood pressure on 414 individuals gave no evidence of any differences between these groups for either systolic or diastolic pressure. The number of individuals that could be regarded as hypertensive in this community-based study was small, but it is concluded that most individuals with headache, and with migraine, have blood pressures similar to those who do not have headaches.

\section{Introduction}

There are widely conflicting opinions about the association of headache and migraine with arterial blood pressure. The view that headache is a common symptom in hypertension (Wolff, 1963; Pickering, 1968) apparently contradicts the statement that "it is generally agreed that moderate hypertension alone does not cause headache" (Selby and Lance, 1960). A recent survey showed no significant differences in the prevalence of headaches in hypertensive patients with diastolic pressures of up to $130 \mathrm{~mm} \mathrm{Hg}$ when compared with normotensive controls selected from other clinics at the same hospital (Al Badran et al., 1970).

A study in general practice concluded that patients with migraine have significantly higher systolic and diastolic pressures than those without migraine and that, age for age, this difference averaged about $10 \mathrm{~mm} \mathrm{Hg}$ (Walker, 1959). Blood pressure levels may, however, fall during migraine attacks (Pfeiffer et al., 1943) and, contrary to the general view, it has even been stated that most patients with migraine tend to have low blood pressures (MacNeal, 1949).

Only about half of all migraine sufferers attend a doctor for their headaches (Waters and O'Connor, 1970) and the proportion of headache sufferers seeking attention is even lower. Therefore only representative community samples can give reliable evidence of any association between headaches and blood pressure.

\footnotetext{
Medical Research Council's Epidemiology Unit (South Wales), Cardiff, CF2 3AS

W. E. WATERS, M.B., D.I.H., Member of Staff (Present appointment : Senior Lecturer in Ćlinical Epidemiology and Community Medicine, University of Southampton)
}

\section{Methods}

Following a survey in which a random sample of 1,838 adults in the Pontypridd area of Glamorgan were sent questionnaires on headache, random samples of individuals with migraine, unilateral headache, headache, and a fourth group without headache in the year immediately preceding the survey were examined. Details of these samples, the response rates, and some ophthalmological data have been published (Waters, 1970). The correlation between the migraine group, identified by the questionnaire, and a neurologist's clinical diagnosis has been measured (Waters and O'Connor, 1970). All arterial blood pressures were measured with a standard mercury manometer by one observer, who is a State-registered nurse, after the individuals had been sitting for at least five minutes. Diastolic pressures were taken at the point when muffling of the sounds occurred. All readings were recorded to the nearest $5 \mathrm{~mm} \mathrm{Hg}$. During the survey the observer was unaware of the headache histories of the individuals examined.

\section{Results}

The mean systolic and diastolic blood pressures, and the standard deviations about these means, are given in Table I. Both systolic and diastolic pressures increased significantly with increasing age. For men the age structure of the four "headache groups" did not differ significantly, and the distributions of systolic and diastolic blood pressure are given in the Chart. Analyses of variance showed no significant difference between the groups for either systolic pressure $(0.1<\mathrm{P}<0.2)$ or diastolic pressure $(0.2<\mathrm{P}<0.3)$.

In women, because of the significantly different age structure of the four headache groups, analyses of variance were done for each of the three age groups 21-34, 35-54, and 55-74 years. In none of these analyses was the variance between groups significantly greater than the variance within groups (at $\mathrm{P}<0.05$ ) for either systolic or diastolic pressure. The number of individuals with systolic pressures of $195 \mathrm{~mm} \mathrm{Hg}$ or greater and with diastolic pressures of $115 \mathrm{~mm} \mathrm{Hg}$ or greater is shown, by headache group, in Table II. These numbers are too small for detailed analysis but certainly do not suggest any predominance in those with headache.

\section{Discussion}

The view, formerly generally held, that headache is a common symptom of hypertension has been challenged, especially 